\title{
Assessment of exposure to influenza $A$ viruses in pigs between weaning and market age
}

Juliana Bonin Ferreira ${ }^{1,2^{*}} \mathbb{B}$, Zvonimir Poljak², Robert Friendship², Éva Nagy ${ }^{3}$, Greg Wideman ${ }^{4}$ and Helena Grgić ${ }^{2}$

\begin{abstract}
Influenza A viruses (IAVs) are common causes of respiratory infection in pigs. The objective of this study was to characterize the circulation of IAVs between weaning and market age on the basis of development of antibody response and molecular epidemiology of detected viruses. Two batches of weaned pigs were followed in the nursery and finisher barns with a sample of 81 and 75 pigs. Nasal swabs and blood samples were collected from individual pigs for virological and serological analyses. A H3N2 subtype virus, of cluster IV, was detected in Study 1, with a maximum of $97.9 \%$ identity to HA gene of viruses previously isolated in Ontario. In Study 2, a H1N1 subtype virus, of 2009 H1N1 pandemic lineage, was detected, with a maximum of $97.8 \%$ identity to HA gene of viruses previously isolated in Ontario. On the basis of HA gene, it was observed that pigs were being detected with the same virus over time. The existence of antibody titers for IAV other than the isolated one confirmed that more than one subtype can circulate in the same population. In Study 1, pigs with higher numbers of IAV detection had lower serological titers for the same virus that was confirmed to circulate in the nursery $(P<0.01)$. Thorough knowledge of all endemic viral strains is fundamental for development of infection and disease control, particularly in complex production systems. This may include consideration of sampling and testing strategies which could detect circulation of all IAV variants, even if they have low prevalence.
\end{abstract}

Keywords: Influenza A virus, Antibodies, Swine, Co-circulation

\section{Introduction}

Influenza, an enzootic disease in many pig populations, is caused by influenza virus type A [1]. Three subtypes can be found circulating in pig barns worldwide: H1N1, H3N2 and H1N2. Prevalence of exposure at the herd level is generally very high. In previous studies, herd-level point prevalence of exposure has been estimated at $83 \%$ and $43 \%$ in Ontario sow and finisher herds, respectively [2]; and above $90 \%$ in sow herds in Belgium and Germany [3]. As in human influenza, the virus causes a self-limiting

*Correspondence: jboninf@ncsu.edu

${ }^{1}$ Department of Population Health and Pathobiology, North Carolina State University, Raleigh, NC, USA

Full list of author information is available at the end of the article respiratory disease in individual animals. It has also been reported that the disease can spread quickly within the herd and disappear within 1-2 weeks [4]. In addition, different studies have reported that transport of weaned pigs can contribute to the dissemination of influenza $A$ virus (IAV) among farms, and that sow herds and neonatal pigs might be important for the maintenance of the virus $[5,6]$.

Recent studies showed that swine influenza viruses can persist within a farm, causing two distinct outbreaks [7]. Additionally, recurrent infections with influenza A viruses in nursery pigs have been reported under field conditions in two different studies [1,8]. Several studies have reported exposure of pigs to more than a single strain or subtype, either cumulatively or concurrently 
$[1,9,10]$. Simultaneous circulation of multiple distinct viruses can lead to reassortment.

Currently, the influenza situation is complex due to the existence of multiple strains that do not necessarily cross-react, as shown in multiple large scale studies [1, $11,12]$. However, even some within-herd studies suggest the presence of multiple strains $[1,9]$. While studies focused on within-herd circulation of influenza virus under contemporary conditions continue to be limited, they are essential for understanding IAV ecology, and for designing infection control measures for IAV.

Therefore, the objective of this study was to characterize the circulation of IAV in pigs between weaning and market age on the basis of the development of antibody response and molecular epidemiology of detected viruses.

\section{Materials and methods}

This research project was approved under University of Guelph AUP 3038.

\section{General overview}

A detailed description of the barn included in this study has been previously provided [13]. Briefly, a nursery farm located in southern Ontario with a total capacity of 4000 animals was selected for the study. The farm was composed of two separate barns of equal capacity (2000 head each). Pigs from five sow-sources, belonging to the same multi-site swine production system, were weaned at approximately 19 days of age, and transported to this one nursery site.

\section{Study population}

The nursery study barn selected for the two longitudinal studies had four equally-sized rooms with individual air flow, each room housing approximately 500 pigs in 24 pens, for a total barn capacity of approximately 2000 pigs. Two finisher sites, belonging to the same system, were included in the study. Finisher site for Study $1 \mathrm{com}$ prised of one single barn, all-in-all-out, with capacity for 2000 pigs. Pens were all located in a single air-space with central hallway and were separated from the exterior by solid walls. Finisher site for Study 2 comprised of 2 barns, with the same characteristics as the one described in Study 1, but on a different geographical location. For the longitudinal studies, 81 piglets and 75 piglets were selected for Study 1 and Study 2, respectively [13]. In each study, the piglets originated from five different sow sources. For Study 1, blood samples were collected at entry to the nursery ( 3 week-old), and at the end of the nursery (10 week-old) from November $18^{\text {th }} 2013$ to January $9^{\text {th }} 2014$ and finisher periods (22-24 week-old) on April $1^{\text {st }}, 11^{\text {th }}$ and $22^{\text {nd }}, 2014$. For Study 2, blood samples were collected at entry to the nursery ( 3 week-old), midnursery (6-7 week-old) and at the end of the nursery (10 week-old) from April $4^{\text {th }} 2014$ to May $29^{\text {th }} 2014$, and at the end of the finisher period (22-25 week-old) August $19^{\text {th }}$ and September $3^{\text {rd }} 2014$. In addition to the pigs followed in Study 2, forty-one pigs not included in the longitudinal study were selected randomly in the finisher barn. The extra pigs were sampled for logistical reasons and because all the study pigs could not be located during the last sampling in the finisher barn.

\section{Serology}

In order to determine the hemagglutination inhibition (HI) titers antibodies at entry to the nursery and also at the mid and end of the nursery period and end of finisher periods, serum samples were analyzed by the HI assay according to standard protocol [14] with four hemagglutinating units per well. The cut-off of $\mathrm{HI}$ titers was set at $\geq 1: 40$ as previously reported [14]. Six swine influenza isolates $[15,16]$ were used for $\mathrm{HI}: \mathrm{A} / \mathrm{SW} / \mathrm{ON} / 103-18 / 11 /$ $\mathrm{H} 3 \mathrm{~N} 2 / \mathrm{HA}, \mathrm{A} / \mathrm{SW} / \mathrm{ON} / 104-25 / 12 / \mathrm{H} 3 \mathrm{~N} 2 / \mathrm{HA}, \mathrm{A} / \mathrm{SW} /$ ON/115-2/12/H3N2/HA, A/SW/ON/68/12/H1N2/HA, $\mathrm{A} / \mathrm{SW} / \mathrm{ON} / 84 / 12 / \mathrm{H} 1 \mathrm{~N} 1 / \mathrm{HA}$, and $\mathrm{A} / \mathrm{SW} / 2 / 81 / \mathrm{H} 1 \mathrm{~N} 1 /$ $\mathrm{HA}$, referred to throughout the article as H3N2_A, H3N2_B, H3N2_C, H1N2, H1N1_P, and H1N1_C, respectively. Also, two viruses identified in these longitudinal studies were used for HI: A/SW/ON/72-7-8/2014/ H3N2 (Study 1) and A/SW/ON/148-9/2014/H1N1 (Study 2), referred to throughout the article as H3N2_H and H1N1_H, respectively. A complete description of the serological testing is reported elsewhere [13].

\section{Detection of influenza A virus}

The presence of IAV in weekly nasal swabs as described in [13] was assessed by isolation and propagation of the virus in Madin-Darby canine kidney (MDCK) cells with added trypsin according to a standard protocol [17]. Virus replication was confirmed on the basis of the cytopathic effect (CPE) produced in the cells and also assessed by the hemagglutination assay according to a standard protocol [17]. Isolated viruses were then sequenced using the Illumina Miseq platform as described earlier [16] and subtyped on the basis of hemagglutinin and neuraminidase and sequenced using a deep sequencing approach. In selecting viruses for sequencing, priority was given to viruses that were detected in pigs with multiple infections over time. The consensus sequence was obtained after mapping the results of deep sequencing to the reference strains of $\mathrm{H} 1 \mathrm{~N} 1$ and H3N2 subtypes. The consensus sequence was used for further phylogenetic analysis. Phylogenetic trees were built using HA nucleotide sequences of included viruses. In addition, previous isolated Ontario strains and selected North American strains 
were included in the phylogenetic analysis. Sequence alignment was conducted using Clustal W algorithm with default parameters in Geneious R9.1. The similarity between isolates was calculated using the Jukes-Cantor approach, and an unrooted tree was built using the complete linkage approach.

\section{Statistical analysis}

Descriptive statistics were generated for each variable and correlation was tested using the Spearman correlation coefficient. Titers were summarized through descriptive statistics and median and interquartile range (IQR) were presented. In addition, the difference in the median of the titers was compared for titers in the longitudinal study and in the cross sectional study (end of finisher), as described elsewhere [18].

Samples from Study 1 (three samplings) and Study 2 (four samplings) were then categorized in order to calculate incidence risk and prevalence determined by the presence of titers. For each of the eight viruses used in the $\mathrm{HI}$ assay, the binary results representing positivity at the start and the end of the nursery and at the end of the finisher phase were classified into four distinct groups: (0) pigs that did not have a positive titer in two subsequent measurements; (1) pigs that had a negative titer at the first measurement and a positive titer in subsequent measurements; (2) pigs that had a positive titer at the first measurement and a negative titer in subsequent measurements; (3) pigs that had a positive titer at the first and in the subsequent measurements. Proportion of pigs in each of the four latter groups was then described for each distinct period of measurement (e.g. between weaning and end of nursery period). In addition, incidence risk was calculated only if, in each of the distinct periods, at least 3 pigs tested negative for antibodies at the start of the period. Prevalence was calculated at the end of nursery and the end of finisher phase using number of animals with positive titers at the time of sampling as the numerator, and number of animals tested as a denominator. For the last measurement in Study 2, prevalence was determined for animals included in the longitudinal study, and additionally using animals that were sampled cross-sectionally.

Linear regression was performed to evaluate the association between the total number of virologically positive results during the nursery phase and the $\log _{2} \mathrm{HI}$ antibody titers at the end of nursery period. The biological hypothesis evaluated here was that the intensity of infection, measured by the cumulative number of positive tests, influences the serological response at the end of the nursery period. Models were evaluated as described elsewhere [19].
Wilcoxon's signed-rank test was performed to analyze the difference in serological response to each of the eight viruses between the measurements conducted at the end of the nursery and finisher phases. The biological hypothesis evaluated here was that time spent during the finisher phase would influence development of antibodies for the eight specific viruses in the finisher barn. Analysis was performed as described elsewhere [18]. Statistical analyses were conducted at the pig level using STATA IC 13 (StataCorp LP, College Station, TX, USA).

\section{Results}

\section{Descriptive analysis}

Descriptive analyses of all variables from both studies are presented in Table 1. In Study 1, eighty-one piglets were tested in the first measurement at entry to nursery, 79 in the second measurement at the end of nursery, and 57 in the third measurement at the end of finisher. In Study 2, seventy-five piglets were tested in the first measurement at entry to nursery, 74 in the second measurement in mid-nursery phase, 73 in the third measurement at end of nursery, and 39 in the fourth measurement at end of finisher. The fourth measurement included pigs in the longitudinal study $(n=39)$ and pigs selected randomly (cross-sectional $n=41$ ) in the finisher barn. The median titers for the pigs included in the longitudinal study and those not included (cross-sectional) did not differ for most of the viruses tested, except H3N2_B and H1N1_H (Table 1). In both cases, titers of pigs randomly selected were higher than those of the pigs in the study. The results of serological testing of sera collected in all three measurements in Study 1 suggested variability in the antibody titers for all eight viruses tested (Figure 1 and Table 1). The titers for all $\mathrm{H} 3$ viruses increased during the nursery phase, while all $\mathrm{H} 1$ titers decreased or remained the same. Spearman correlation coefficients among the titers of different $\mathrm{HI}$ tests at each sampling occasion for study 1 are depicted in Additional file 1. At the entry to nursery, results showed a positive correlation amongst all titers with nine Spearman correlation coefficients ranging between 0.5 and 0.8 . In the latter samplings correlation among titers varied in the direction and magnitude (Additional file 1).

Serological results from samples collected in all four measurements in Study 2 suggested variability in the antibody titers for all eight viruses tested (Figure 2 and Table 1). Titers for H3N2_A decreased in the nursery, but increased in the finisher barn. For all the other H3 viruses, titers decreased or remained the same in both production sites. Titers for H1N1_P increased at the end of nursery and finisher phases, while H1N1_H titers increased at the end of nursery phase and decreased at the end of finisher phase. Spearman correlation 
Table 1 Descriptive statistics of the measurements and frequency tables in the study of influenza $A$ virus circulation

\begin{tabular}{|c|c|c|c|c|}
\hline \multirow[t]{2}{*}{ Variable } & \multicolumn{2}{|l|}{ Study 1} & \multicolumn{2}{|l|}{ Study 2} \\
\hline & $\begin{array}{l}\text { Median } \\
\text { (IQR) }\end{array}$ & $\begin{array}{l}\text { N positive }{ }^{ \pm} \\
(\%)\end{array}$ & $\begin{array}{l}\text { Median } \\
\text { (IQR) }\end{array}$ & N positive (\%) \\
\hline
\end{tabular}

\begin{tabular}{|c|c|c|c|c|}
\hline \multicolumn{5}{|l|}{ H3N2_A* } \\
\hline $1^{11}$ & $10(15)$ & $15(18.5)$ & $40(40)$ & $66(88.0)$ \\
\hline 2 & - & - & $10(10)$ & $8(10.8)$ \\
\hline 3 & 80 (120) & 77 (97.4) & $5(0)$ & $0(0)$ \\
\hline $\begin{array}{l}4 \text { (pigs in } \\
\text { study) }\end{array}$ & $40(60)$ & 35 (61.4) & $80(0)$ & 37 (97.3) \\
\hline $4 \backslash$ & - & - & $80(0)$ & 78 (98.7) \\
\hline \multicolumn{5}{|l|}{ H3N2_B ${ }^{*}$} \\
\hline 1 & $40(60)$ & $49(60.4)$ & $160(80)$ & $72(96.0)$ \\
\hline 2 & - & - & $40(20)$ & $51(68.9)$ \\
\hline 3 & $80(120)$ & 70 (88.6) & $20(10)$ & $16(21.9)$ \\
\hline $\begin{array}{l}4 \text { (pigs in } \\
\text { study) }\end{array}$ & $80(40)$ & $52(91.2)$ & $10(10)$ & $8(21.0)$ \\
\hline 4 & - & - & $20(70)$ & $38(48.1)$ \\
\hline \multicolumn{5}{|l|}{ H3N2_C $C^{*}$} \\
\hline 1 & $20(30)$ & $39(48.1)$ & 80 (120) & $61(81.3)$ \\
\hline 2 & - & - & $20(30)$ & $20(27.0)$ \\
\hline 3 & 80 (1270) & $42(54.4)$ & $10(5)$ & $5(6.8)$ \\
\hline $\begin{array}{l}4 \text { (pigs in } \\
\text { study) }\end{array}$ & $10(5)$ & $1(1.7)$ & $10(5)$ & $2(2.5)$ \\
\hline 4 & - & - & $10(5)$ & $2(5.2)$ \\
\hline \multicolumn{5}{|l|}{$\mathrm{H} 3 \mathrm{~N} 2 \mathrm{H}^{+}$} \\
\hline 1 & $40(140)$ & $60(74.0)$ & $80(120)$ & $67(89.3)$ \\
\hline 2 & - & - & $20(30)$ & $19(25.6)$ \\
\hline 3 & $80(120)$ & $63(79.7)$ & $10(5)$ & $3(4.1)$ \\
\hline $\begin{array}{l}4 \text { (pigs in } \\
\text { study) }\end{array}$ & $20(10)$ & $12(21.0)$ & $5(0)$ & $1(2.6)$ \\
\hline 4 & - & - & $5(5)$ & $3(3.8)$ \\
\hline \multicolumn{5}{|l|}{$\mathrm{H} 1 \mathrm{N2}^{\ddagger}$} \\
\hline 1 & $40(20)$ & $43(53.0)$ & 80 (120) & $62(82.6)$ \\
\hline 2 & - & - & $20(30)$ & $22(29.7)$ \\
\hline 3 & $10(5)$ & $0(0)$ & $5(5)$ & $4(5.4)$ \\
\hline $\begin{array}{l}4 \text { (pigs in } \\
\text { study) }\end{array}$ & $10(5)$ & $1(1.7)$ & $10(0)$ & $1(2.6)$ \\
\hline 4 & - & - & $10(0)$ & $3(3.8)$ \\
\hline \multicolumn{5}{|l|}{ H1N1_C ${ }^{\S}$} \\
\hline 1 & $10(15)$ & 7 (8.6) & $10(15)$ & 14 (18.6) \\
\hline 2 & - & - & $5(0)$ & $0(0)$ \\
\hline 3 & $5(0)$ & $3(3.8)$ & $5(0)$ & $2(2.7)$ \\
\hline $\begin{array}{l}4 \text { (pigs in } \\
\text { study) }\end{array}$ & $5(0)$ & $0(0)$ & $5(5)$ & $1(2.6)$ \\
\hline 4 & - & - & $5(5)$ & $1(1.2)$ \\
\hline \multicolumn{5}{|l|}{ H1N1_Pף } \\
\hline 1 & $10(15)$ & $15(18.5)$ & $20(30)$ & $24(32.0)$ \\
\hline 2 & - & - & $20(10)$ & $15(20.2)$ \\
\hline 3 & $10(5)$ & $1(1.2)$ & $20(30)$ & $33(45.2)$ \\
\hline $\begin{array}{l}4 \text { (pigs in } \\
\text { study) }\end{array}$ & $10(10)$ & $0(0)$ & $40(40)$ & $35(92.1)$ \\
\hline
\end{tabular}

Table 1 (continued)

\begin{tabular}{|c|c|c|c|c|}
\hline \multirow[t]{2}{*}{ Variable } & \multicolumn{2}{|l|}{ Study 1} & \multicolumn{2}{|l|}{ Study 2} \\
\hline & $\begin{array}{l}\text { Median } \\
\text { (IQR) }\end{array}$ & $\begin{array}{l}\text { N positive } \\
(\%)\end{array}$ & $\begin{array}{l}\text { Median } \\
\text { (IQR) }\end{array}$ & N positive (\%) \\
\hline 4 & - & - & $40(40)$ & $66(83.5)$ \\
\hline \multicolumn{5}{|l|}{$\mathrm{H} 1 \mathrm{~N} 1 \mathrm{H}^{+}$} \\
\hline 1 & $40(70)$ & $42(51.8)$ & $20(30)$ & $22(29.3)$ \\
\hline 2 & - & - & $5(5)$ & $4(5.4)$ \\
\hline 3 & $20(20)$ & $39(49.3)$ & $80(140)$ & $54(73.9)$ \\
\hline $\begin{array}{l}4 \text { (pigs in } \\
\text { study) }\end{array}$ & $5(5)$ & $0(0)$ & $20(30)$ & 15 (39.4) \\
\hline 4 & - & - & $40(60)$ & 45 (56.9) \\
\hline
\end{tabular}

The two longitudinal studies were performed in nursery pigs, between November $18^{\text {th }}, 2013$ and January $9^{\text {th }}$ and between April $4^{\text {th }}, 2014$ and May $29^{\text {th }}$, 2014, respectively. Fourth measurement was taken at the end of finisher period. Median and interquartile range were used. Any titer $<1: 10$ was treated, for the purpose of analysis, as 5 .

* Different H3N2 variants broadly classified into cluster 4 of H3N2 swine influenza A virus and isolated in Ontario in 2012 and used in the hemagglutination inhibition assay.

${ }^{+} \mathrm{H} 3 \mathrm{~N} 2$ and $\mathrm{H} 1 \mathrm{~N} 1$ viruses detected in the study and used as antigens in the hemagglutination inhibition assay.

* H1N2 with hemagglutinin of the 2009 pandemic lineage and neuraminidase of the Cluster $4 \mathrm{H} 3 \mathrm{~N} 2 \mathrm{IAV}-\mathrm{S}$.

$\S \mathrm{H} 1 \mathrm{~N} 1 \mathrm{IAV}-\mathrm{S}$ broadly classified as the classical swine H1N1 virus used in hemagglutinin inhibition assay.

" H1N1 IAV-S of the 2009 H1N1 pandemic lineage used in the hemagglutination inhibition assay.

"Number of blood sampling performed: (1) entry to nursery, (2) mid-nursery, (3) end of nursery, (4) end of finisher.

' Sum of pigs in the longitudinal study and pigs selected randomly in the finisher barn.

${ }^{ \pm}$Number of pigs that had a positive titer $(\geq 1: 40)$ in each of the measurements.

coefficients among the titers of different $\mathrm{HI}$ tests at each sampling occasion for study 2 are depicted in Additional file 2 . At the entry to nursery, strong positive correlation was observed among tests with different H3N2 viruses and $\mathrm{H} 1 \mathrm{~N} 2$ virus, and separately among $\mathrm{H} 1 \mathrm{~N} 1$ viruses. Descriptively, correlation weakened in absolute value over the duration of the study (Additional file 2).

Grouping of individual pigs into different categories on the basis of the change in titers for each virus during the nursery and the finisher phase in Study 1 and Study 2 is provided in Tables 2 and 3, respectively. In Study 1, the incidence for H3N2_A, H3N2_B, and H3N2_H in the nursery was $96 \%, 93 \%$, and $95 \%$, respectively. Point prevalence was also high: $97 \%, 88 \%$ and $79 \%$, respectively, for these same viruses. In the finisher barn, the prevalence for H3N2_A and H3N2_B was 61\% and 91\%, respectively. Different results can be observed in Study 2. The incidence for H3N2_B (66\%), H1N1_P (52\%), and H1N1_H (76\%) was high in the nursery phase. In the finisher phase, the incidence for H3N2_A (97\%), H1N1_P (95\%), and H1N1_H (76\%) was also high. The prevalence for $\mathrm{H} 1 \mathrm{~N} 1 \mathrm{H}_{\mathrm{H}}(73 \%)$ was high in the nursery phase. 

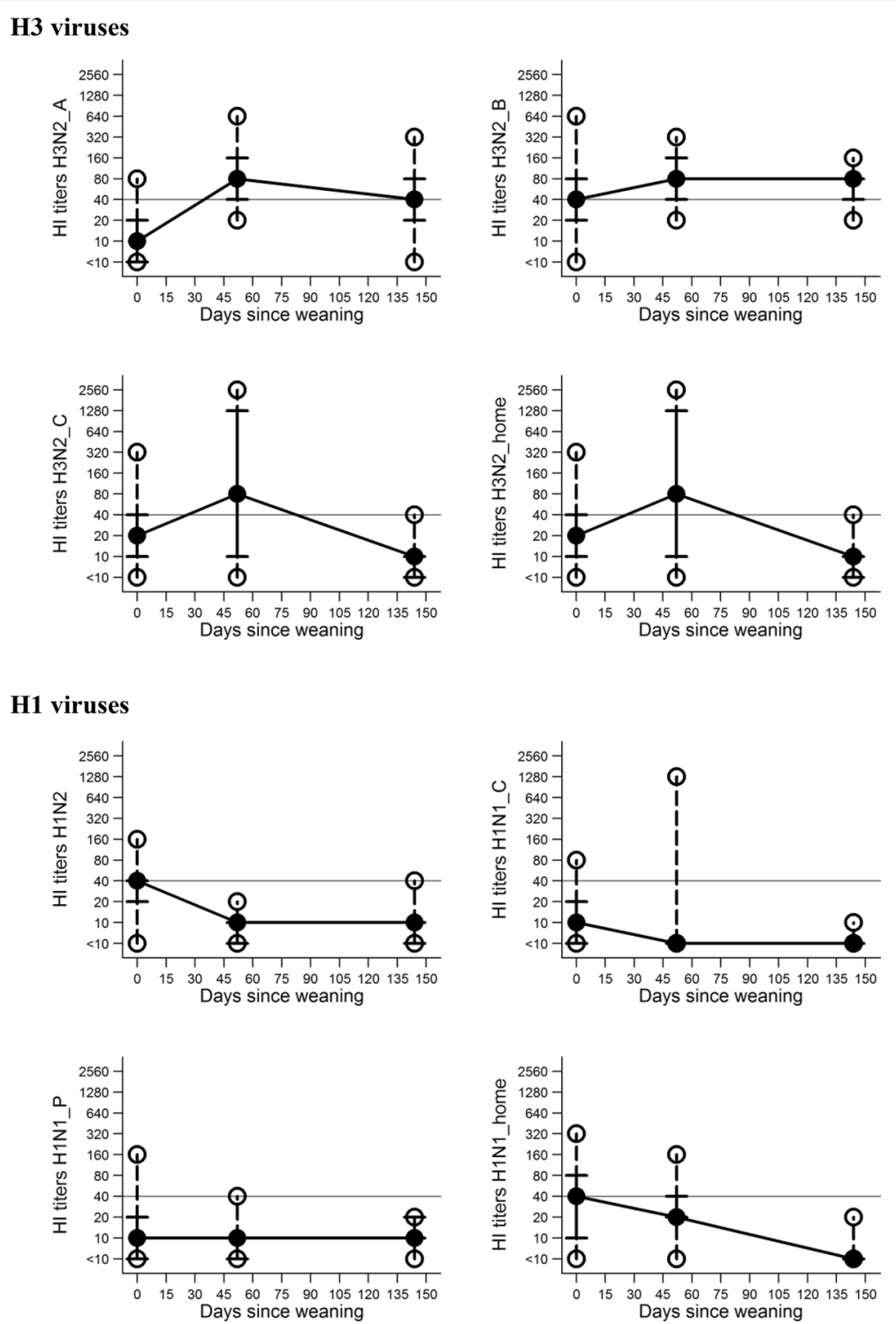

Figure 1 Serological (HI test) titers of monitored pigs in three different measurements—Study $\mathbf{1}$. Median represented by the solid black circle, p25 and p75 represented by the vertical lines, minimum and maximum represented by the hollow circles are shown representing the variability of titers throughout the study. The horizontal line represents the threshold for positive titers 1:40.

In the finisher phase, the prevalence for H3N2_A (97\%), H1N1_P (92\%) and H1N1_H (73\%) was also high. Overall mortality in the barn was $1.8 \%$ and $1.9 \%$ for Study 1 and 2 , respectively.

\section{Detection of influenza A virus}

In order to present results for the detection of IAV, there is the need to briefly describe results showed in [13].

\section{Study 1}

As previously shown, pigs were virologically positive up to four times. Pigs were sampled weekly during the nursery period, totaling 7 samplings (1 sampling/week), although sampling in the first week consisted of several sampling occasions to accommodate sampling of pigs shortly upon their arrival from different sow herds. Overall, of 81 pigs, 38 (46.9\%) were positive once, 16 (19.7\%) were positive twice, and $27(33.3 \%)$ were positive three or more times [13]. Isolated viruses were sequenced and all isolates were characterized as identical or very similar viruses, herein named A/SW/ON/72-7-8/2014/ H3N2. Phylogenetic analysis showed that the isolated viruses belonged to cluster IV on the basis of HA gene analysis (Figure 3). Identity of the majority of viruses was 

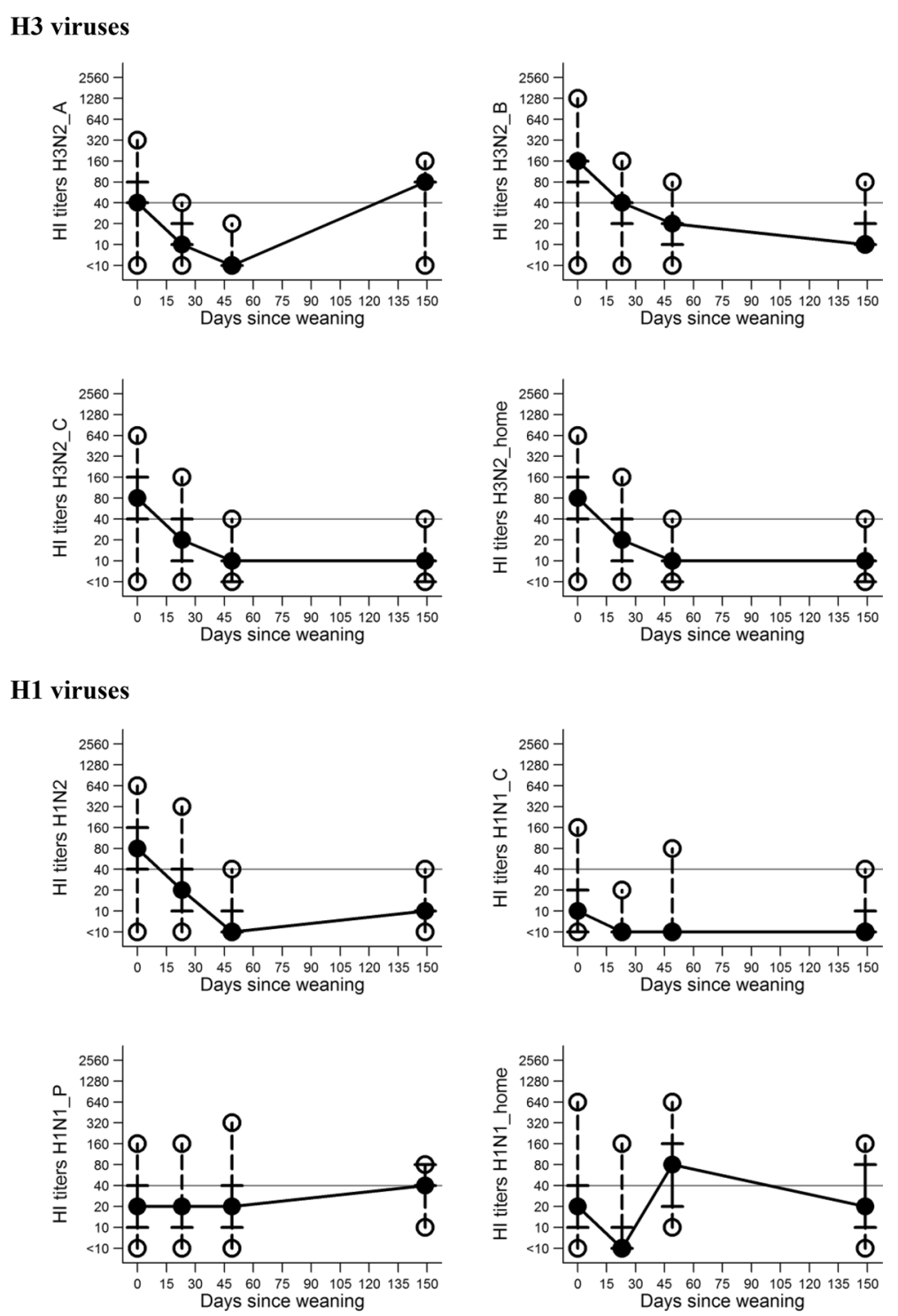

Figure 2 Serological (HI test) titers of monitored pigs in four different measurements-Study 2. Median represented by the solid black circle, p25 and p75 represented by the vertical lines, minimum and maximum represented by the hollow circles are shown representing the variability of titers throughout the study. The horizontal line represents the threshold for positive titers 1:40.

between 99.9 and 100\% (i.e., maximum of 2 nucleotides), with only a single isolate having a minimum identity of 99.1\% when compared to other viruses detected in Study 1 (Figure 3). However, when compared to other H3N2 viruses previously isolated in Ontario, identity was $93.8 \%$, 97.9\%, and $94.2 \%$ to H3N2_A, H3N2_B, and H3N2_C, respectively. Labels of the study viruses in Figure 3 (e.g. $\mathrm{A} / \mathrm{SW} / \mathrm{ON} / 81-5 / 14 / \mathrm{H} 3 \mathrm{~N} 2 / \mathrm{HA})$ contain unique pig identifier (e.g., 81 in the latter example), and sampling occasion (e.g., occasion 5 in the latter example). Therefore, pigs that repeatedly tested positive for IAV and had their viruses sequenced, were found to have nucleotide sequences of the IAVs' HA gene with $99.9 \%$ identity or higher, except in the case of one pig when the identity between viruses affecting the same pig on different occasions was 99.2\% (Figure 3).

\section{Study 2}

Overall, of the 75 pigs, virus was never identified from 27 (36\%), whereas $36(48 \%)$ were positive once, and $12(16 \%)$ were positive two or more times. Isolated viruses were sequenced and all isolates were characterized as identical viruses, herein named A/SW/ON/148-9/2014/H1N1. Phylogenetic analysis showed that isolated viruses belong 
Table 2 Incidence and prevalence in the nursery and finisher phase in Study 1 and frequency table indicating percentage of pigs with a distinct change in the serological status at the end of each production phase

\begin{tabular}{|c|c|c|c|c|c|c|c|c|c|}
\hline \multicolumn{2}{|c|}{ Phase of production and categories } & \multicolumn{8}{|l|}{$\%$} \\
\hline & & H3N2_A* & H3N2_B ${ }^{*}$ & H3N2_C $C^{*}$ & $\mathrm{H} 3 \mathrm{~N}_{2} \mathrm{H}^{+}$ & $\mathrm{H}_{1} \mathrm{~N}^{\ddagger}$ & H1N1_Pn & H1N1_C & $\mathrm{H} 1 \mathrm{N1}{ }_{-} \mathrm{H}^{+}$ \\
\hline \multirow[t]{7}{*}{ Nursery } & Incidence $^{* *}(\%)(95 \% \mathrm{Cl})$ & $\begin{array}{l}96 \\
(0.89,0.99)\end{array}$ & $\begin{array}{l}93 \\
(0.78,0.99)\end{array}$ & $\begin{array}{l}55 \\
(0.38,0.70)\end{array}$ & $\begin{array}{l}95 \\
(0.76,0.99)\end{array}$ & $\begin{array}{l}0 \\
-\end{array}$ & $\begin{array}{l}0 \\
-\end{array}$ & $\begin{array}{l}4 \\
(0.01,0.11)\end{array}$ & $\begin{array}{l}48 \\
(0.32,0.65)\end{array}$ \\
\hline & Prevalence (\%) (95\% Cl) & $\begin{array}{l}97 \\
(0.91,0.99)\end{array}$ & $\begin{array}{l}88 \\
(0.79,0.94)\end{array}$ & $\begin{array}{l}53 \\
(0.41,0.64)\end{array}$ & $\begin{array}{l}79 \\
(0.69,0.87)\end{array}$ & $\begin{array}{l}0 \\
-\end{array}$ & $\begin{array}{l}1 \\
(0.01,0.06)\end{array}$ & $\begin{array}{l}3 \\
(0.01,0.10)\end{array}$ & $\begin{array}{l}49 \\
(0.37,0.60)\end{array}$ \\
\hline & \multicolumn{9}{|c|}{ Proportion of study animals in strata defined by the serological exposure status at the start and end of study period } \\
\hline & $\mathrm{N}-\mathrm{N}^{1}$ & 2.4 & 2.4 & 22.0 & 1.2 & 43.9 & 78.1 & 84.2 & 24.4 \\
\hline & $N-P^{2^{*} \&}$ & 75.6 & 35.4 & 26.8 & 24.4 & 0.0 & 0.0 & 3.7 & 23.2 \\
\hline & $\mathrm{P}-\mathrm{N}^{3}$ & 0.0 & 8.5 & 23.2 & 18.3 & 52.4 & 17.1 & 8.5 & 24.4 \\
\hline & $P-P^{4^{*}}$ & 18.3 & 50.0 & 24.4 & 52.4 & 0.0 & 1.2 & 0.0 & 24.4 \\
\hline \multirow[t]{8}{*}{ Finisher } & Incidence (\%) (95\% Cl) & - & - & 0 & 0 & 1 & 0 & 0 & 0 \\
\hline & & & & - & - & $(0.01,0.09)$ & - & - & - \\
\hline & Prevalence (\%) (95\% Cl) & $\begin{array}{l}61 \\
(0.47,0.74)\end{array}$ & $\begin{array}{l}91 \\
(0.80,0.97)\end{array}$ & $\begin{array}{l}1 \\
(0.01,0.09)\end{array}$ & $\begin{array}{l}19 \\
(0.10,0.31)\end{array}$ & $\begin{array}{l}1 \\
(0.01,0.09)\end{array}$ & $\begin{array}{l}0 \\
-\end{array}$ & $\begin{array}{l}0 \\
-\end{array}$ & $\begin{array}{l}0 \\
-\end{array}$ \\
\hline & \multicolumn{9}{|c|}{ Proportion of study animals in strata defined by the serological exposure status at the start and end of study period } \\
\hline & $\mathrm{N}-\mathrm{N}$ & 0.0 & 0.0 & 32.9 & 15.9 & 67.1 & 67.1 & 65.9 & 35.4 \\
\hline & $\mathrm{N}-\mathrm{P}$ & 1.2 & 9.8 & 0.0 & 0.0 & 1.2 & 0.0 & 0.0 & 0.0 \\
\hline & $\mathrm{P}-\mathrm{N}$ & 26.8 & 6.1 & 34.2 & 37.8 & 0.0 & 1.2 & 2.4 & 32.9 \\
\hline & P-P & 40.2 & 52.4 & 1.2 & 14.6 & $0(0)$ & 0.0 & 0.0 & 0.0 \\
\hline \multicolumn{10}{|c|}{$\begin{array}{l}\text { " Different H3N2 variants broadly classified into cluster } 4 \text { of H3N2 swine influenza A virus and isolated in Ontaric } \\
\text { assay. }\end{array}$} \\
\hline \multicolumn{10}{|c|}{${ }^{\dagger} \mathrm{H} 3 \mathrm{~N} 2$ and $\mathrm{H} 1 \mathrm{~N} 1$ viruses detected in the study and used as antigens in the hemagglutination inhibition assay. } \\
\hline \multicolumn{10}{|c|}{${ }^{\ddagger} \mathrm{H} 1 \mathrm{~N} 2$ with hemagglutinin of the 2009 pandemic lineage and neuraminidase of the Cluster 4 H3N2 IAV-S. } \\
\hline \multicolumn{10}{|c|}{${ }^{\S} \mathrm{H} 1 \mathrm{~N} 1 \mathrm{IAV}-\mathrm{S}$ broadly classified as the classical swine $\mathrm{H} 1 \mathrm{~N} 1$ virus used in the hemagglutination inhibition assay. } \\
\hline \multicolumn{10}{|c|}{ " H1N1 IAV-S of the $2009 \mathrm{H} 1 \mathrm{~N} 1$ pandemic lineage used in the hemagglutination inhibition assay. } \\
\hline \multicolumn{10}{|c|}{${ }^{1}$ Negative titers in both measurements. } \\
\hline \multicolumn{10}{|c|}{$2^{*} \&$ Negative titers in the measurement at the end of nursery and positive titers at the end of finisher. Used to calculate prevalence ${ }^{*}$ and incidence risk ${ }^{\&}$. } \\
\hline \multicolumn{10}{|c|}{${ }^{3}$ Positive titers in the measurement at the end of nursery and negative titers at the end of finisher. } \\
\hline \multicolumn{10}{|c|}{$4^{*}$ Positive titers in the measurement at the end of nursery and positive titers at the end of finisher. Used to calculate prevalence. } \\
\hline \multicolumn{10}{|c|}{ ** Incidence was only calculated if more than three pigs were positive. } \\
\hline
\end{tabular}

to cluster pH1N1 on the basis of HA gene analysis (Figure 4). Identity of the isolated viruses was a minimum of $99.82 \%$ with a maximum of three different nucleotides. However, when compared to other H1N1 previously isolated in Ontario identity was $97.8 \%$ and $97.7 \%$ for A/ $\mathrm{SW} / \mathrm{ON} / 84 / 12 / \mathrm{H} 1 \mathrm{~N} 1 / \mathrm{HA}$, and $\mathrm{A} / \mathrm{SW} / 2 / 81 / \mathrm{H} 1 \mathrm{~N} 1 / \mathrm{HA}$, respectively. Labels of the study viruses in Figure 4 (e.g. $\mathrm{A} / \mathrm{SW} / \mathrm{ON} / 148-9 / 14 / \mathrm{H} 1 \mathrm{~N} 1 / \mathrm{HA})$ contain unique pig identifier (e.g., 148 in the latter example), and sampling occasion (e.g., occasion 9 in the latter example).

Linear regression Table 4 shows results for the linear regression model for both studies. For Study 1, pigs with 3 or more positive results in the virological test had lower $\log _{2}$ titers than the referent category $(P<0.05)$ in the nursery barn for H3N2_H, also shown graphically in Figure 5. Similar result was observed for H3N2_B; while for H3N2_C a positive association between number of posi- tive results and $\log _{2} \mathrm{H} 3 \mathrm{~N} 2$ _C titers was observed $(P<0.05)$. For all other variables, statistically significant results were not observed (data not shown). For Study 2, the opposite situation was observed for the same H3N2_H. Pigs with 2 or more positive results in the virological test had higher $\log _{2}$ titers than the referent category $(P<0.05)$. For all other variables, there was no statistically significant association between the number of positive results and $\log _{2}$ titers (data not shown).

Wilcoxon's signed-rank test Results for the Wilcoxon's signed-rank test are presented in Table 5. In Study 1, serological titers based on seven of eight viruses changed significantly over time. However, for six of these seven viruses statistically significant results were associated with the decrease in titers at the end of the finisher period. The only exception was H1N1_P, where an increase in titers for a larger number of pigs was observed (Table 5). 
Table 3 Incidence and prevalence in the nursery and finisher phase in Study 2 and frequency table indicating percentage of pigs with a distinct change in the serological status at the end of each production phase

\begin{tabular}{|c|c|c|c|c|c|c|c|c|c|}
\hline \multicolumn{2}{|c|}{ Phase of production and categories } & \multicolumn{8}{|l|}{$\%$} \\
\hline & & H3N2_A* & H3N2_B* & H3N2_C $C^{*}$ & $\mathrm{H} 3 \mathrm{~N}_{2} \mathrm{H}^{\dagger}$ & $\mathrm{H} 1 \mathrm{~N}^{\ddagger}$ & H1N1_Pף & H1N1_C $C^{\S}$ & $\mathrm{H} 1 \mathrm{~N} 1 \mathrm{H}^{\dagger}$ \\
\hline \multirow[t]{7}{*}{ Nursery } & Incidence (\%) (95\% Cl) & $\begin{array}{l}0 \\
-\end{array}$ & $\begin{array}{l}66 \\
(0.09,0.99)\end{array}$ & $\begin{array}{l}0 \\
-\end{array}$ & $\begin{array}{l}0 \\
-\end{array}$ & $\begin{array}{l}0 \\
-\end{array}$ & $\begin{array}{l}52 \\
(0.37,0.66)\end{array}$ & $\begin{array}{l}3 \\
(0.01,0.11)\end{array}$ & $\begin{array}{l}76 \\
(0.63,0.87)\end{array}$ \\
\hline & Prevalence (\%) (95\% Cl) & $\begin{array}{l}0 \\
-\end{array}$ & $\begin{array}{l}21 \\
(0.13,0.33)\end{array}$ & $\begin{array}{l}6 \\
(0.02,0.15)\end{array}$ & $\begin{array}{l}4 \\
(0.01,0.11)\end{array}$ & $\begin{array}{l}5 \\
(0.01,0.13)\end{array}$ & $\begin{array}{l}45 \\
(0.33,0.57)\end{array}$ & $\begin{array}{l}2 \\
(0.01,0.09)\end{array}$ & $\begin{array}{l}73 \\
(0.62,0.83)\end{array}$ \\
\hline & Proportion of study anim & Is in strata de & ned by the se & ological expo & ure status at $t$ & e start and er & of study per & & \\
\hline & $\mathrm{N}-\mathrm{N}^{\mathrm{a}}$ & 12.0 & 1.3 & 18.6 & 10.6 & 17.3 & 32.0 & 77.3 & 16.0 \\
\hline & $N-P^{b \neq \&}$ & 0.0 & 2.6 & 0.0 & 0.0 & 0.0 & 34.7 & 2.6 & 53.3 \\
\hline & $\mathrm{P}-\mathrm{N}^{\mathrm{c}}$ & 85.3 & 74.6 & 72.0 & 82.6 & 74.6 & 21.3 & 17.3 & 9.3 \\
\hline & $P-P^{d} \neq$ & 0.0 & 18.6 & 6.6 & 4.0 & 5.3 & 9.3 & 0.0 & 18.6 \\
\hline \multirow[t]{7}{*}{ Finisher } & Incidence (\%) (95\% Cl) & $\begin{array}{l}97 \\
(0.86,0.99)\end{array}$ & $\begin{array}{l}26 \\
(0.12,0.45)\end{array}$ & $\begin{array}{l}5 \\
(0.01,0.19)\end{array}$ & $\begin{array}{l}2 \\
(0.01,0.14)\end{array}$ & $\begin{array}{l}2 \\
(0.01,0.14)\end{array}$ & $\begin{array}{l}95 \\
(0.78,0.99)\end{array}$ & $\begin{array}{l}3 \\
(0.01,0.11)\end{array}$ & $\begin{array}{l}76 \\
(0.63,0.87)\end{array}$ \\
\hline & Prevalence (\%) (95\% Cl) & $\begin{array}{l}97 \\
(0.86,0.99)\end{array}$ & $\begin{array}{l}21 \\
(0.09,0.37)\end{array}$ & $\begin{array}{l}5 \\
(0.01,0.17)\end{array}$ & $\begin{array}{l}2 \\
(0.01,0.13)\end{array}$ & $\begin{array}{l}2 \\
(0.01,0.13)\end{array}$ & $\begin{array}{l}92 \\
(0.78,0.98)\end{array}$ & $\begin{array}{l}2 \\
(0.01,0.09)\end{array}$ & $\begin{array}{l}73 \\
(0.62,0.83)\end{array}$ \\
\hline & Proportion of study anim & Is in strata de & ned by the se & ological expo & ure status at & e start and er & of study per & & \\
\hline & $\mathrm{N}-\mathrm{N}$ & 1.3 & 29.3 & 42.7 & 46.7 & 46.7 & 1.3 & 77.3 & 16.0 \\
\hline & $\mathrm{N}-\mathrm{P}$ & 49.3 & 10.7 & 2.7 & 1.3 & 1.3 & 29.3 & 2.6 & 53.3 \\
\hline & $\mathrm{P}-\mathrm{N}$ & 0.0 & 10.7 & 5.3 & 2.7 & 2.7 & 2.7 & 17.3 & 9.3 \\
\hline & P-P & 0.0 & 0.0 & 0.0 & 0.0 & 0.0 & 17.3 & 0.0 & 18.6 \\
\hline \multicolumn{10}{|c|}{$\begin{array}{l}\text { "Different H3N2 variants broadly classified into cluster } 4 \text { of H3N2 swine influenza A virus and isolated in Ontario in } 2012 \text { and used in the hemagglutination inhibition } \\
\text { assay. }\end{array}$} \\
\hline \multicolumn{10}{|c|}{${ }^{\dagger} \mathrm{H} 3 \mathrm{~N} 2$ and $\mathrm{H} 1 \mathrm{~N} 1$ viruses detected in the study and used as antigens in the hemagglutination inhibition assay. } \\
\hline \multicolumn{10}{|c|}{${ }^{\ddagger} \mathrm{H} 1 \mathrm{~N} 2$ with hemagglutinin of the 2009 pandemic lineage and neuraminidase of the Cluster 4 H3N2 IAV-S. } \\
\hline \multicolumn{10}{|c|}{${ }^{\S} \mathrm{H} 1 \mathrm{~N} 1 \mathrm{IAV}-\mathrm{S}$ broadly classified as the classical swine H1N1 virus used in the hemagglutination inhibition assay. } \\
\hline \multicolumn{10}{|c|}{ " H1N1 IAV-S of the 2009 H1N1 pandemic lineage used in the hemagglutination inhibition assay. } \\
\hline \multicolumn{10}{|c|}{${ }^{a}$ Negative titers in both measurements. } \\
\hline \multicolumn{10}{|c|}{$b^{*} \&$ Negative titers in the measurement at the end of nursery and positive titers at the end of finisher. Used to calculate prevalence ${ }^{*}$ and incidence risk ${ }^{\&}$. } \\
\hline \multicolumn{10}{|c|}{${ }^{\mathrm{C}}$ Positive titers in the measurement at the end of nursery and negative titers at the end of finisher. } \\
\hline \multicolumn{10}{|c|}{$d^{*}$ Positive titers in the measurement at the end of nursery and positive titers at the end of finisher. Used to calculate prevalence ${ }^{*}$. } \\
\hline
\end{tabular}

In Study 2, serological titers based on five out of eight viruses changed significantly over time. In this study, the titers for H1N1_H predominantly decreased at the end of the finisher period (Table $5, P<0.01 ; 66 \%$ of animals), whereas the titers for H3N2_A predominantly increased (Table $5, P<0.01,97 \%$ of animals). Such a result was consistent with the development of titers in pigs over a period of time as shown in Figure 2.

\section{Discussion}

To expand our understanding of the development of antibodies to specific IAVs and what the factors might be to trigger the response, we combined repeated sampling and laboratory findings based on the combination of serological testing based on multiple influenza virus variants of the three common subtypes, including viruses detected in this specific barn.

This study confirmed that multiple influenza viruses were able to circulate in the same population during a relatively short period of time. All viruses in Study 1 were typed as H3N2 subtype and all were within a minimum of $99.7 \%$ identity of HA gene, although these viruses were obtained from the same animals that were repeatedly positive on virus isolation. This finding suggests that the same viable virus could be repeatedly detected from the same pig during a nursery phase over time period that extends typical period of infectiousness.

In Study 2, the H1N1 virus broadly classified into pandemic lineage A (H1N1)pdm09 emerged and was detected in pigs even on repeated samplings. This circulation of $\mathrm{H} 1 \mathrm{~N} 1$ virus might have been associated with management practices. Newly weaned pigs in Study 2 had relatively high $\mathrm{HI}$ titers for $\mathrm{H} 3 \mathrm{~N} 2$ viruses, likely because maternally derived antibodies (MDA) were derived through application of the H3N2-based autogenous vaccination of sows before farrowing. In this statement there is the assumption that the antibodies detected at entry to the nursery were due to MDA. The autogenous vaccine 


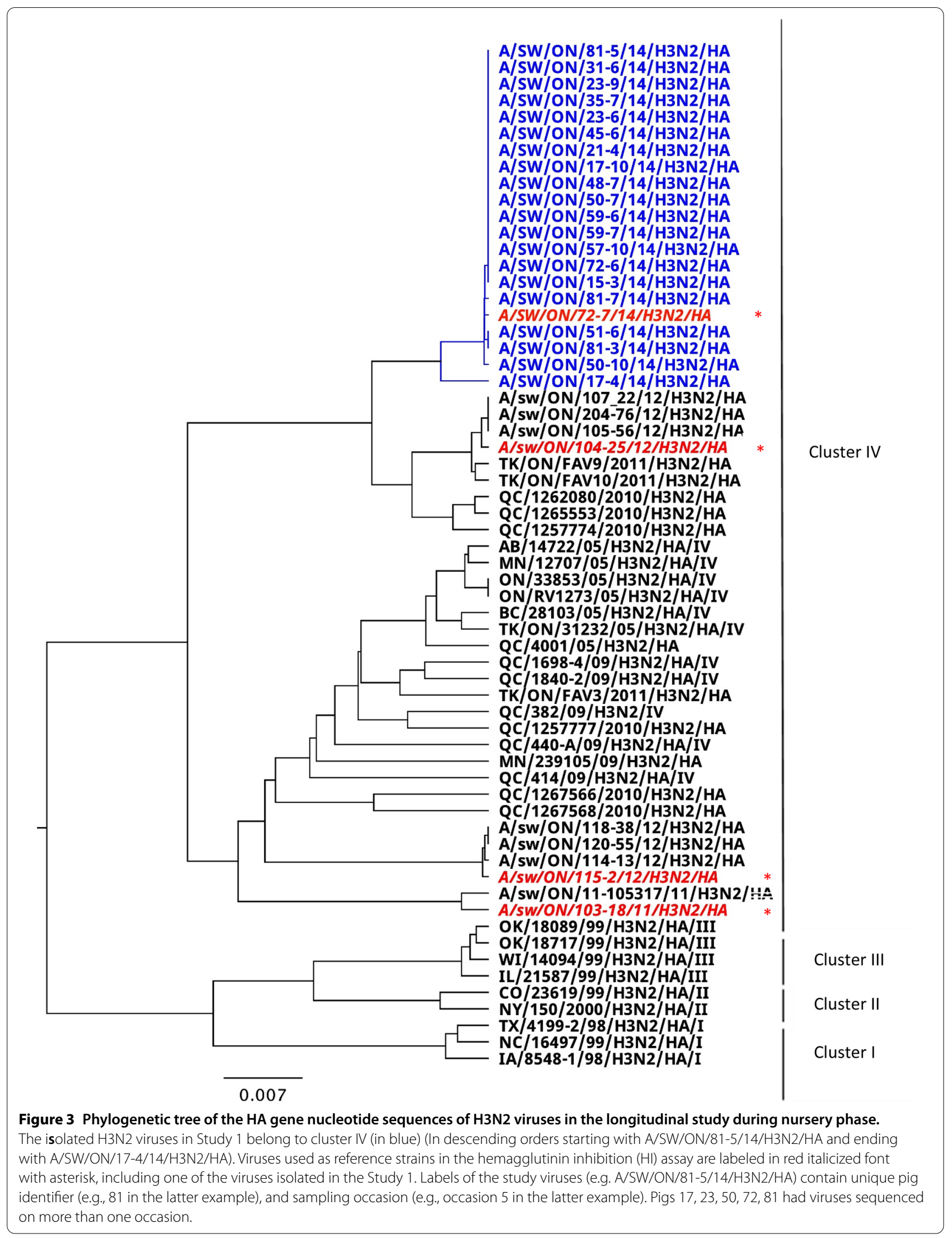




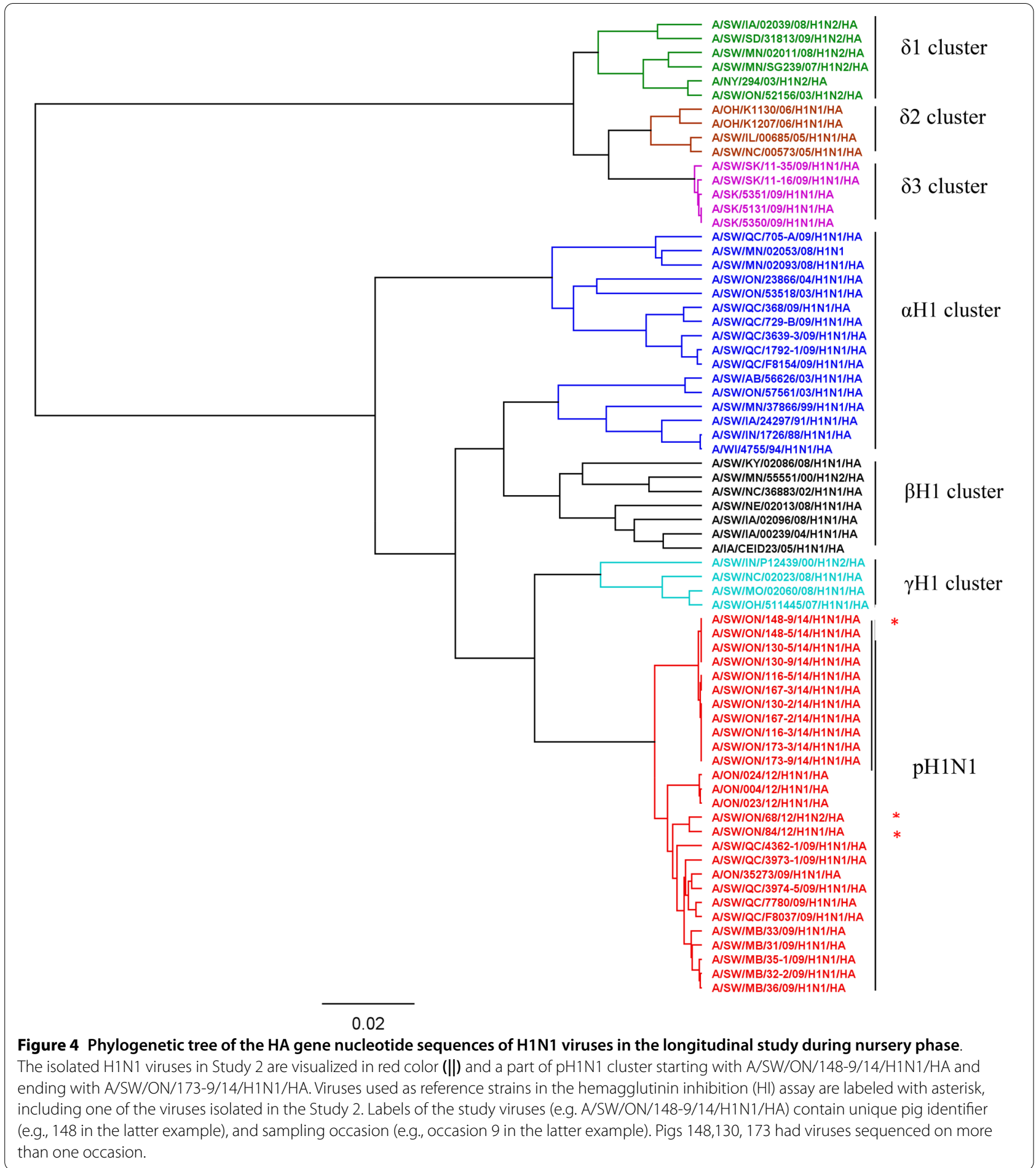

was implemented in response to repeated respiratory issues in the production system that was confirmed to be caused by different H3N2 IAV strains. Such vaccination strategy might have had an impact on decreasing the incidence of H3N2 infection, which could not be detected on the basis of virus isolation in Study 2. Nonetheless, H1N1 viruses started to circulate in the nursery and contribute to influenza incidence. In Study 1 and 2, circulation of different subtypes in the nursery was confirmed by genome sequencing of a number of viruses and by the 
Table 4 Linear regression models for analysis of titers for influenza $A$ based on the number of positive results

\begin{tabular}{|c|c|c|c|c|c|}
\hline & \multirow{2}{*}{$\begin{array}{l}\text { Variable } \\
\text { Study } 1\end{array}$} & \multicolumn{4}{|c|}{ Linear regression } \\
\hline & & Coef & SE & P & $95 \% \mathrm{Cl}$ \\
\hline \multirow[t]{10}{*}{ Nursery } & $\mathrm{H} 3 \mathrm{~N}_{2} \mathrm{H}^{\ddagger}$ & & & $0.01^{ \pm}$ & \\
\hline & $2 \backslash$ & -0.9 & 0.44 & 0.03 & $-1.86,-0.08$ \\
\hline & $3^{11}$ & -1.6 & 0.37 & 0.01 & $-2.40,-0.92$ \\
\hline & H3N2_C & & & $0.01^{ \pm}$ & \\
\hline & 2 & 4.10 & 1.01 & 0.01 & $2.08,6.13$ \\
\hline & 3 & 2.28 & 0.84 & 0.01 & $0.58,3.97$ \\
\hline & H3N2_B & & & $0.03^{ \pm}$ & \\
\hline & 2 & -0.54 & 0.32 & 0.10 & $-1.19,0.11$ \\
\hline & 3 & -0.68 & 0.27 & 0.01 & $-1.23,-0.14$ \\
\hline & Study 2 & & & & \\
\hline \multirow[t]{3}{*}{ Nursery } & $\mathrm{H} 3 \mathrm{~N} 2 \mathrm{H}^{\ddagger}$ & & & $0.06^{ \pm}$ & \\
\hline & $1^{¥}$ & 0.06 & 0.22 & 0.78 & $-0.38,0.50$ \\
\hline & $2^{¥ \neq}$ & 0.67 & 0.29 & 0.02 & $0.08,1.27$ \\
\hline
\end{tabular}

\footnotetext{
₹ The original titer divided by 10 and then $\log _{2}$ transformed.

I Pigs were positive twice. Reference category was that pigs were positive once.

" Pigs were positive 3 or 4 times. Reference category was that pigs were positive once.

$¥$ Pigs were positive once. Reference category was that pigs were never positive.

¥ Pigs were positive twice or 3 times. Reference category was that pigs were never positive.

${ }^{ \pm} P$-value obtained by testing categorical variable using a partial likelihood test.
}

increase in titers against $\mathrm{H} 3 \mathrm{~N} 2$ and $\mathrm{H} 1 \mathrm{~N} 1$ viruses at the end of nursery phase of Study 1 and Study 2, respectively.

Isolation of viruses from finisher pigs was not attempted for logistic reasons. However, development of antibody titers between the end of the nursery and the end of the finisher phase indicated further differences in influenza dynamics between the two cohorts. In the Study 1, titers for almost all viruses decreased, perhaps suggesting that there was no further significant circulation of any influenza viruses in the finisher barn. The H1N1_P was the only virus for which there was a statistical increase in titers between the end of nursery and the end of finisher phase; however, the prevalence of this virus based on formal declaration of a positive titer at the end of the finisher phase was $0 \%$ indicating that the statistical increase in titers was likely not of any practical significance. In Study 2, titers for the H1N1_H virus primarily decreased, suggesting that this virus did not circulate after the nursery phase while titers for the H1N1_P increased suggesting that virus of this lineage might also have been circulating in the finisher barn. In contrast, titers for H3N2_A increased in almost all pigs, suggesting that this virus was likely circulating in the finisher barn. This was the only H3N2 virus that showed such a marked increase, and was the virus that was only $93.8 \%$ identical to the H3N2_H virus isolated in Study 1. Taken collectively, these results therefore suggest that at least three distinct viruses were circulating in these 2 cohorts (H3N2_H, H1N1_H, and H3N2_A-like).

Circulation of multiple viruses in the same population is not a novel finding. A study conducted in Europe reported that co-circulation of different viruses is possible [1]. The authors reported that different subtypes were detected simultaneously in the same animal in all farms included in the study [1]. In another European study different $\mathrm{H} 1 \mathrm{~N} 1$ viruses were detected in the same farm during the study period [8]. Also in agreement with our findings, in a study conducted in Ontario antibodies for $\mathrm{H} 3 \mathrm{~N} 2$ and $\mathrm{H} 1 \mathrm{~N} 1$ viruses were detected on the same farms [10] and a recent American study also reports finding multiple viruses on the same farm [20]. However, the novelty of the present study was the in-depth investigation on the basis of different strains. The results imply that in the studied system, and possibly in other systems with similar complex animal flows, multiple viruses might circulate, creating complex patterns. Further research is needed to elucidate factors influencing such co-circulation, including the impact of cross-reactivity, maternal and active immunity, contact structure, and stochasticity. From the standpoint of practical infection control, the important issue is that the knowledge of all viruses and influenza virus genes in the production system need to be well understood before infection control measures are designed or implemented. Such knowledge should perhaps be gained by sampling and testing strategies that consider low prevalence of circulation for some influenza variants. Infection control measures based on the assumption of a single dominant virus might be oversimplification in complex systems. Another interesting finding was that the pigs which were positive by virus isolation on multiple occasions during the nursery phase had lower titers for the identical virus (H3N2_H) at the end of the nursery phase. Similar results were obtained for H3N2_B (97.9\% identity with H3N2_H), but not for H3N2_C (94.2\% identity with H3N2_H). This trend showed a negative dose-response relationship. This finding was interesting because it suggests that multiple infections with the same virus during the nursery phase do not necessarily lead to development of strong active immunity against that virus. In fact, multiple infections and low level of active immunity at the end of the nursery period might be a consequence of an inability of pigs to mount an effective immune response against a specific virus. This might be because of the presence of maternal immunity for a heterologous virus, which allows infection with a specific virus and prevents development of active immunity against that specific virus. Similar results were observed in an experimental study based on inoculation of sows with $\mathrm{H} 1 \mathrm{~N} 1$ and challenge of piglets 


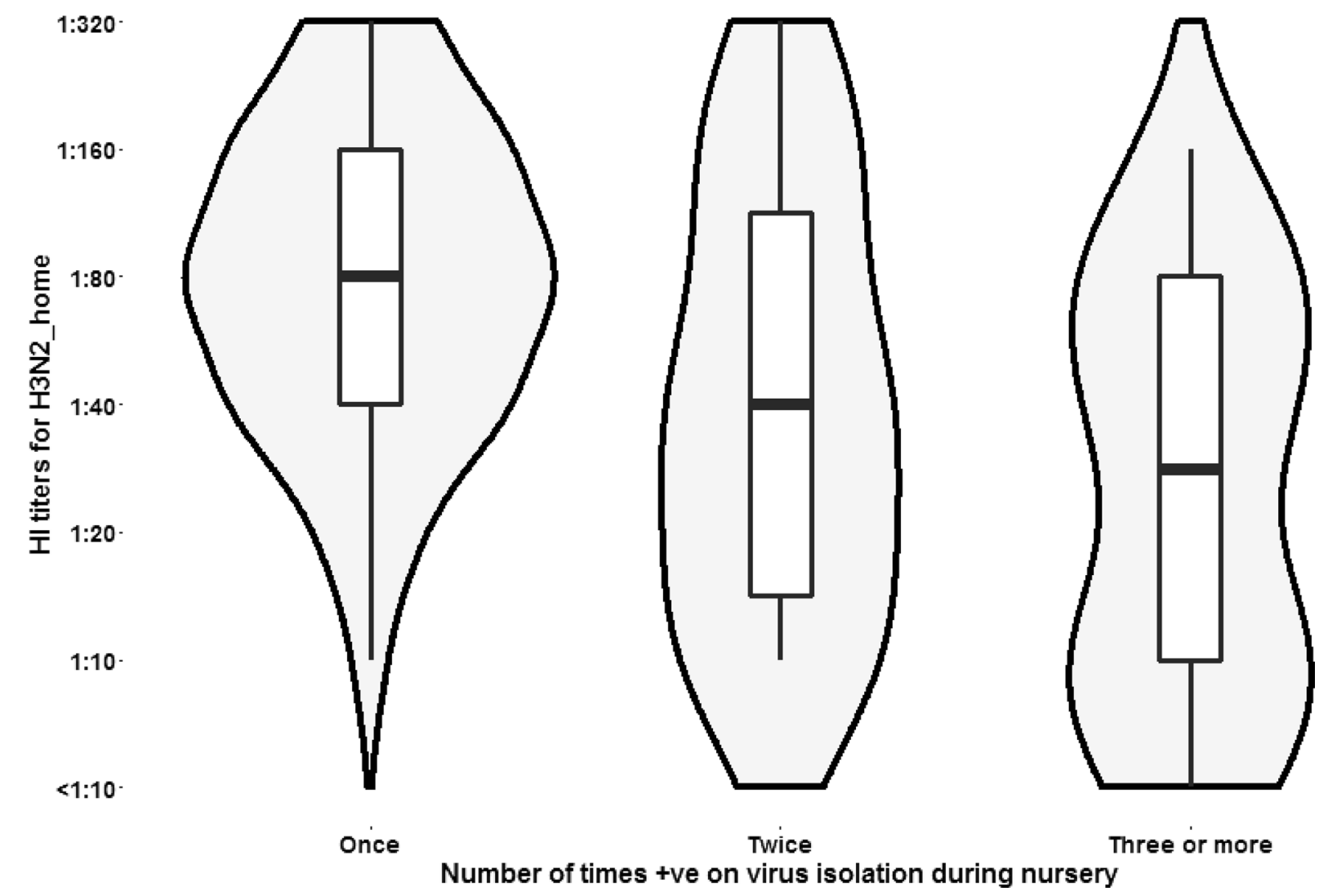

Figure 5 Antibody response against H3N2_H among pigs positive with the virus at one, two, or three or more samplings. The figure demonstrates that there is a negative dose-response relationship. The wider shape of the box/violin plot in the higher titer area of the figure is for pigs with one isolation of virus corresponds to the proportion of pigs with this result.

with the same strain (strain-homologous). It has been observed [12] that pigs with passive immunity or MDA, coming from inoculated sows, expressed fewer and less severe clinical signs after inoculation with the same strain used to induce immunity in sows; however, they were not totally protected against infection. Moreover, active immunity was delayed or absent in the presence of MDA [12]. Another similar experimental study showed that the active immunity can be delayed when maternal antibodies are present [21]. It has been shown, in another study, that recurrent infections are possible in pigs with MDA for $\mathrm{H} 1 \mathrm{~N} 1, \mathrm{H} 1 \mathrm{~N} 2$ and $\mathrm{H} 3 \mathrm{~N} 2$ viruses when challenged with homologous IAV subtypes. It was also reported that pigs in the finisher barn seroconverted, showing that the absence of the MDA allowed active immunity to develop [1]. Researchers have also evaluated the ability of MDA to provide protection against a heterologous challenge and showed that the presence of MDA, for a specific virus, in non-vaccinated piglets, can suppress the development of active immunity (subtype-heterologous) [11]. In agreement with the findings of the present study, Allerson et al. suggested that IAV infection can occur in the presence of
MDA. Groups of pigs were exposed to viruses that were subtype-homologous and subtype-heterologous to the MDA acquired from sow vaccination. Results showed that infection was present in pigs exposed to subtypeheterologous virus [22]. Another study showed that the presence of MDA did not prevent replication, however it did confer some clinical protection. MDA also impacted humoral and cellular responses, delaying the latter [23]. Findings from a different study showed that the presence of MDA can reduce IAV transmission, however, the reproduction number can be higher than 1, supporting that the presence of MDA might not protect against shedding of the virus [24]. All referenced studies showed that the presence of MDA can interfere with the humoral response and pigs were not fully protected against new infections.

\section{Limitations}

Sequencing of all isolated viruses could not be performed due to high cost. In addition some assumptions could not be made for some of the analyses, such as the increase of titers when pigs were infected two or more times with 
Table 5 Wilcoxon paired signed-rank test of level of titers of pigs at the end of nursery period compared to level of titers at the end of the finisher period

\begin{tabular}{|c|c|c|c|c|}
\hline \multirow[t]{2}{*}{ Variable } & \multicolumn{2}{|l|}{ Study 1} & \multicolumn{2}{|l|}{ Study 2} \\
\hline & Observed & $P$-value & Observed & $P$-value \\
\hline \multicolumn{5}{|l|}{$\mathrm{H} 3 \mathrm{~N} 2 \mathrm{~A}^{*}$} \\
\hline Decreased titers $>$ & 35 & 0.01 & 1 & 0.01 \\
\hline |ncreased titers $>>$ & 8 & & 37 & \\
\hline No difference ${ }^{\neq}$ & 13 & & 0 & \\
\hline \multicolumn{5}{|l|}{ H3N2_B $B^{*}$} \\
\hline Decreased titers & 32 & 0.01 & 15 & 0.76 \\
\hline Increased titers & 14 & & 12 & \\
\hline No difference & 10 & & 11 & \\
\hline \multicolumn{5}{|l|}{ H3N2_C ${ }^{*}$} \\
\hline Decreased titers & 39 & 0.01 & 11 & 0.57 \\
\hline Increased titers & 7 & & 14 & \\
\hline No difference & 10 & & 13 & \\
\hline \multicolumn{5}{|l|}{$\mathrm{H} 3 \mathrm{~N} 2{ }_{2} \mathrm{H}^{+}$} \\
\hline Decreased titers & 51 & 0.01 & 15 & 0.02 \\
\hline Increased titers & 2 & & 5 & \\
\hline No difference & 3 & & 18 & \\
\hline \multicolumn{5}{|l|}{$\mathrm{H} 1 \mathrm{~N}^{\ddagger}$} \\
\hline Decreased titers & 17 & 0.88 & 4 & 0.01 \\
\hline Increased titers & 17 & & 16 & \\
\hline No difference & 22 & & 18 & \\
\hline \multicolumn{5}{|l|}{ H1N1_P } \\
\hline Decreased titers & 11 & 0.05 & 10 & 0.01 \\
\hline Increased titers & 24 & & 25 & \\
\hline No difference & 21 & & 3 & \\
\hline \multicolumn{5}{|l|}{ H1N1_C $C^{\S}$} \\
\hline Decreased titers & 15 & 0.01 & 3 & 0.07 \\
\hline Increased titers & 2 & & 9 & \\
\hline No difference & 39 & & 26 & \\
\hline \multicolumn{5}{|l|}{$\mathrm{H} 1 \mathrm{~N} 1 \mathrm{H}^{\dagger}$} \\
\hline Decreased titers & 54 & 0.01 & 25 & 0.01 \\
\hline Increased titers & 0 & & 1 & \\
\hline No difference & 2 & & 12 & \\
\hline Total $\|^{\#}$ & 56 & & 38 & \\
\hline
\end{tabular}

Comparison was made for the same pig having time as "treatment".

* Different H3N2 variants broadly classified into cluster 4 of H3N2

swine influenza A virus and isolated in Ontario in 2012 and used in the hemagglutination inhibition assay.

${ }^{+} \mathrm{H} 3 \mathrm{~N} 2$ and $\mathrm{H} 1 \mathrm{~N} 1$ viruses detected in the study and used as antigens in the hemagglutination inhibition assay.

₹ $\mathrm{H} 1 \mathrm{~N} 2$ with hemagglutinin of the 2009 pandemic lineage and neuraminidase of the Cluster $4 \mathrm{H} 3 \mathrm{~N} 2 \mathrm{IAV}-\mathrm{S}$

$\S \mathrm{H} 1 \mathrm{~N} 1 \mathrm{IAV}-\mathrm{S}$ broadly classified as the classical swine H1N1 virus used in the hemagglutination inhibition assay.

9 H1N1 IAV-S of the $2009 \mathrm{H} 1 \mathrm{~N} 1$ pandemic lineage used in the hemagglutination inhibition assay.

\# Total number of the pigs sampled at the end of finisher.

$>$ Pigs presented higher titers in the end of nursery when compared to the end of finisher.

>> Pigs presented lower titers at the end of nursery when compared to the end of finisher.

$\neq$ There is no difference in pigs titers at the end of nursery when compared to the end of finisher.
H3N2_C in Study 1, and for H3N2_H in Study 2. Also, the viruses that were sequenced were isolated viruses and propagated in MDCK cells. Some viruses may not have replicated well in the culture or one virus out-competed others.

In conclusion, this study demonstrates that multiple strains and subtypes of influenza A viruses can circulate in the same pig population during a relatively short period of time. Factors that influence patterns of such circulation deserve to be studied in greater detail for a variety of reasons. From a practical infection-control perspective, thorough knowledge of all endemic viral strains and important influenza genes is needed as the basis for development of infection and disease control, particularly in complex production systems that seem to dominate in current swine production. This may include consideration of sampling and testing strategies which could detect circulation of all IAV variants, even if they have low prevalence.

\section{Abbreviations}

IAVs: Influenza A viruses; IAV: Influenza A virus; HI: Hemagglutination inhibition; MDCK: Madin-Darby canine kidney; CPE: Cytopathic effect; IQR: Interquartile range; MDA: Maternally derived antibodies.

\section{Supplementary Information}

The online version contains supplementary material available at https://doi. org/10.1186/s13567-021-00927-9.

Additional file 1. Spearman correlation coefficient of hemagglutination titers of pig sera tested by eight different antigens in a longitudinal Study 1 of influenza circulation in growing pigs. Panel 1 represents entry to nursery, Panel 2 represents end of nursery phase, and Panel 3 represents correlation at the end of finisher phase.

Additional file 2. Spearman correlation coefficient of hemagglutination titers of pig sera tested by eight different in a longitudinal Study 2 of influenza circulation in growing pigs. Panel 1 represents entry to nursery, Panel 2 represents mid-nursery phase, Panel 3 represents end of nursery phase, and Panel 4 represents correlation at the end of finisher phase.

\section{Acknowledgements}

The researchers would like to thank the Ontario Veterinary College (Guelph, $\mathrm{ON}$, Canada) for financial support to JBF and the participating pork producers.

\section{Authors' contributions}

This paper was written in partial fulfillment of the requirements of a DVSC in swine health management degree. Farm visits, data collection and analysis were done by JBF with assistance from ZP as to best practices. The first draft of this paper was written by JBF and revisions by other authors were incorporated by JBF. HG coordinated the laboratory work (isolation, HA, HI tests, ELISA) and interpreted the laboratory data. RF is the primary advisor for JBF's DVSC work and was involved in critical analysis and revision of the manuscript and final approvals. ZP is an advisor for JBF's DVSc work and was involved in design and conceptualization of the project and interpretation of results. $\mathrm{HG}, \mathrm{EN}$ and GW were involved in critical analysis and revision of the manuscript and final approvals. All authors read and approved the final manuscript. 


\section{Funding}

The researchers would like to thank the Ontario Pork, Swine Innovation Porc, Agriculture and Agri-Food Canada, and Ontario Ministry of Agriculture, Food and Rural Affairs (OMAFRA) for financial support for the development of the study.

\section{Availability of data and materials}

Not Applicable_-pork producers confidential data.

\section{Declarations}

\section{Competing interests}

The authors declare they have no competing interests.

\section{Author details}

${ }^{1}$ Department of Population Health and Pathobiology, North Carolina State University, Raleigh, NC, USA. ${ }^{2}$ Department of Population Medicine, University of Guelph, Guelph, ON, Canada. ${ }^{3}$ Department of Pathobiology, University of Guelph, Guelph, ON, Canada. ${ }^{4}$ South-West Veterinary Ontario Services, Stratford, ON, Canada.

Received: 3 November 2020 Accepted: 23 March 2021

Published online: 21 April 2021

\section{References}

1. Rose N, Hervé S, Eveno E, Barbier N, Eono F, Dorenlor V, Andraud M, Camsusou C, Madec F, Simon G (2013) Dynamics of influenza A virus infections in permanently infected pig farms: evidence of recurrent infections, circulation of several swine influenza viruses and reassortment events. Vet Res 44:72. https://doi.org/10.1186/1297-9716-44-72

2. Poljak Z, Dewey CE, Martin SW, Christensen J, Carman S, Friendship RM (2008) Prevalence of and risk factors for influenza in southern Ontario swine herds in 2001 and 2003. Can J of Vet Res 72:7-17

3. Van Reeth $\mathrm{K}$, Brown IH, Dürrwald R, Foni E, Labarque G, Lenihan P, Maldonado J, Markowska-Daniel I, Pensaert M, Pospisil Z, Koch G (2008) Seroprevalence of H1N1, H3N2 and H1N2 influenza viruses in pigs in seven European countries in 2002-2003. Influenza Other Respir Viruses 2:99-105. https://doi.org/10.1111/j.1750-2659.2008.00043.x

4. Van Reeth K, Brown IH, Olsen CW (2012) Influenza virus. In Diseases of swine, pp. 557-571

5. Allerson MW, Davies PR, Gramer MR, Torremorell M (2014) Infection dynamics of pandemic 2009 H1N1 influenza virus in a two-site swine herd. Transbound Emerg Dis 61:490-499. https://doi.org/10.1111/tbed. 12053

6. Diaz A, Perez A, Sreevatsan S, Davies P, Culhane M, Torremorell M (2015) Association between influenza A virus infection and pigs subpopulations in endemically infected breeding herds. PLoS One 10:e0129213. https:// doi.org/10.1371/journal.pone.0129213

7. Kyriakis CS, Rose N, Foni E, Maldonado J, Loeffen WLA, Madec F, Simon G, Van Reeth K (2013) Influenza A virus infection dynamics in swine farms in Belgium, France, Italy and Spain, 2006-2008. Vet Microbiol 162:543-550. https://doi.org/10.1016/j.vetmic.2012.11.014

8. Simon-Grifé M, Martín-Valls GE, Vilar MJ, Busquets N, Mora-Salvatierra M, Bestebroer TM, Fouchier RA, Martín M, Mateu E, Casal J (2012) Swine influenza virus infection dynamics in two pig farms; results of a longitudinal assessment. Vet Res 43:24. https://doi.org/10.1186/1297-9716-43-24

9. Anderson TK, Nelson MI, Kitikoon P, Swenson SL, Korslund JA, Vincent AL (2013) Population dynamics of cocirculating swine influenza A viruses in the United States from 2009 to 2012. Influenza Other Respir Viruses 7:42-51. https://doi.org/10.1111/irv.12193
10. Poljak Z, Carman S, McEwen B (2014) Assessment of seasonality of influenza in swine using field submissions to a diagnostic laboratory in Ontario between 2007 and 2012. Influenza Other Respir Viruses 8:482-492. https://doi.org/10.1111/irv.12248

11. Kitikoon P, Nilubol D, Erickson BJ, Janke BH, Hoover TC, Sornsen SA, Thacker EL (2006) The immune response and maternal antibody interference to a heterologous $\mathrm{H} 1 \mathrm{~N} 1$ swine influenza virus infection following vaccination. Vet Immunol Immunopathol 112:117-128. https://doi.org/ 10.1016/j.vetimm.2006.02.008

12. Loeffen WL, Heinen P, Bianchi AT, Hunneman W, Verheijden JH (2003) Effect of maternally derived antibodies on the clinical signs and immune response in pigs after primary and secondary infection with an influenza H1N1 virus. Vet Immunol Immunopathol 92:23-35. https://doi.org/10. 1016/S0165-2427(03)00019-9

13. Ferreira JB, Grgić H, Friendship R, Wideman G, Nagy É, Poljak Z (2017) Longitudinal study of influenza A virus circulation in a nursery swine barn. Vet Res 48:63. https://doi.org/10.1186/s13567-017-0466-x

14. Kitikoon P, Gauger PC, Vincent AL (2014) Hemagglutinin inhibition assay with swine sera. Methods Mol Biol 1161:295-301. https://doi.org/10. 1007/978-1-4939-0758-8_24

15. Grgić H, Costa M, Friendship RM, Carman S, Nagy É, Poljak Z (2015) Genetic characterization of H1N1 and H1N2 influenza A viruses circulating in Ontario pigs in 2012. PLoS One 10:e0127840. https://doi.org/10. 1371/journal.pone.0127840

16. Grgić H, Costa M, Friendship RM, Carman S, Nagy É, Wideman G, Weese S, Poljak Z (2014) Molecular characterization of H3N2 influenza A viruses isolated from Ontario swine in 2011 and 2012. Virol J 11:1-14. https://doi. org/10.1186/s12985-014-0194-z

17. Swenson SL (2008) Manual of Diagnostic Tests and Vaccines for Terrestrial Animals. Sixth edition, volume 2

18. Snedegor WG, Cochran GW (1967) Statistical Methods, $6^{\text {th }}$ edn. The lowa State Press, Ames

19. Dohoo I, Martin W, Stryhn H (2009) Veterinary Epidemiologic Research, $2^{\text {nd }}$ edn. VER Inc., Charlotte, PEI

20. Nirmala J, Perez A, Culhane MR, Allerson MW, Sreevatsan S, Torremorell M (2020) Genetic variability of influenza A virus in pigs at weaning in Midwestern United States swine farms. Transbound Emerg Dis 68:62-75. https://doi.org/10.1111/tbed.13529

21. Romagosa A, Allerson M, Gramer M, Joo HS, Deen J, Detmer S, Torremorell M (2011) Vaccination of influenza a virus decreases transmission rates in pigs. Vet Res 42:120. https://doi.org/10.1186/1297-9716-42-120

22. Allerson M, Deen J, Detmer SE, Gramer MR, Joo HS, Romagosa A, Torremorell M (2013) The impact of maternally derived immunity on influenza A virus transmission in neonatal pig populations. Vaccine 31:500-505. https://doi.org/10.1016/j.vaccine.2012.11.023

23. Deblanc C, Hervé S, Gorin S, Cador C, Andraud M, Quéguiner S, Barbier N, Paboeuf F, Rose N, Simon G (2018) Maternally-derived antibodies do not inhibit swine influenza virus replication in piglets but decrease excreted virus infectivity and impair post-infectious immune responses. Vet Microbiol 216:142-152. https://doi.org/10.1016/j.vetmic.2018.01.019

24. Cador C, Hervé S, Andraud M, Gorin S, Paboeuf F, Barbier N, Quéguiner S, Deblanc C, Simon G, Rose N (2016) Maternally-derived antibodies do not prevent transmission of swine influenza A virus between pigs. Vet Res 47:86. https://doi.org/10.1186/s13567-016-0365-6

\section{Publisher's Note}

Springer Nature remains neutral with regard to jurisdictional claims in published maps and institutional affiliations. 